\title{
Chapter 2 \\ Current Trends in Roman Demography and Empirical Approaches to the Dynamics of the Limes Populations
}

\author{
Isabelle Séguy
}

\begin{abstract}
Based on the three principal and inevitably incomplete information sources on ancient historical demography, and taking into account the particularities of the populations living around the Limes Germanicus, a largely male population of soldiers and migrants, this chapter examines the factors that may have influenced their dynamics over the short, medium and long term. It also looks at the possible consequences of increased pressure on the environment, heightened risk of epidemics linked to the rise in population concentration, long-distance communication and adverse climate changes observed from the second half of the second century AD. The proposed empirical approach aims to shed light on the factors that shaped the dynamics of these very specific populations over the long term.
\end{abstract}

Keywords Migration · Border populations · Environmental crises ·

Reconstruction of population dynamics

\subsection{Introduction}

The creation of a frontier region at the northern boundary of the Roman Empire and its survival over three centuries were highly dependent upon the living conditions and demographic behaviours of the populations who lived there or in neighbouring areas, be it temporarily or permanently. The stationing of a military population with specific socio-demographic characteristics and material needs in a populated zone, even if sparsely inhabited, necessarily gave rise to confrontation, change and adaptation in all areas of life (economic, social, cultural, technical, demographic, etc.).

What can we learn about the demographic behaviours of the populations of Ancient Rome, and to what extent can we reconstruct the dynamics of the peoples of the Limes Germanicus with a reasonable level of confidence? What sources do

I. Séguy $(\bowtie)$

French Institute for Demographic Studies (INED), Paris, France

e-mail: seguy@ined.fr 
we have for studying ancient populations? Among the main findings of the various disciplinary approaches, which ones might be relevant to the populations of the limes? Last, which specific demographic features should be taken into account when modelling the history of populations in a frontier region over a dozen generations? We will address these three points successively, after recalling several key concepts of historical demography, considered in the broadest sense. This discipline has the same objectives and uses the same vocabulary as the demography of contemporary populations; only the sources and the associated analysis methods are different. Historical demography studies the structures (age-sex distributions) ${ }^{1}$ and behaviours (fertility, mortality and migration) of past populations as defined at specific moments in time and space.

Demographic analysis also seeks to identify changes in these populations in a dynamic perspective and to explain the causes and consequences of these changes. Interactions between the age-sex structure of a population and its demographic laws (fertility, mortality and migration) govern its evolution over time. Changes in these attributes (size, structure, dynamics and density) can be predicted for a particular population if its fertility, mortality and migration rates are known (projection to forecast its future or retro-projection to reconstruct a part of its past) or inferred (by means of modelling).

As these are historical populations, we must apply the parameters specific to preindustrial populations, defined as largely rural and with no access to modern healthcare. These populations predate the demographic and epidemiological transitions $^{2}$ that began in Europe (France) at the end of the eighteenth century and which led to a sharp rise in life expectancy at birth, notably thanks to a spectacular reduction in infant mortality. By adding extra years to the mean length of life, these transitions also modified other key parameters of demographic dynamics, i.e. mortality, fertility and population age structure. To model the survival probabilities of preindustrial populations, and all associated behaviours, the variables of current demographic models must be adapted accordingly or specific new models developed.

\footnotetext{
${ }^{1}$ The population age-sex distribution - also known as the "population pyramid" - describes the composition of a population at a precise moment, like a snapshot. But it is also a memory of its past events and a strong predictor of its future.

2 "Demographic transition: shift in a population from a traditional demographic regime marked by high fertility and mortality to a modern demographic regime in which fertility and mortality are low". https://www.ined.fr/en/glossary/demographic-transition/

"Epidemiological transition or health transition: the period of mortality decline which accompanies the demographic transition. It is characterized by improved health, nutrition and organization of health services and a change in the causes of death, with mortality from infectious diseases progressively being replaced by mortality from chronic and degenerative diseases and accidents". https://www.ined.fr/en/glossary/epidemiological-transition/
} 


\subsection{A Brief Review of Sources and Methods to Study Roman Demography}

For Roman times (and later periods), three main categories of data are available for demographic approaches, each with its own biases and modes of analysis and each offering a fragment of the history of populations and their demographic behaviour.

Historical demography uses written sources, like ancient censuses, epigraphs, gravestones or literary sources, to reconstruct the size, spatial distribution, composition (by sex, age, marital status and household) of populations and to track their evolution over time. Certain demographic parameters, in terms of mortality, fertility and migration, can then be calculated by applying equations that link these different variables. As these written sources are often limited and fragmentary, quantitative results give limited insights, but can be complemented by qualitative approaches. The available documents generally concern very specific, mainly urban, populations from the southern part of the Roman Empire. Of course, while this approach provides useful information about demographic behaviour in ancient times, its results cannot be directly transposed to other populations living in the Roman Empire. Numerous academic publications concern the demography of ancient times, offering us a good overview of the Roman family and the demography of Mediterranean part of the Roman Empire. Good syntheses are given by Holleran and Pudsey (2011), De Ligt and Northwood (2008), De Ligt (2012), Pelgrom (2012) and Hin (2015).

Archaeological demography is based solely on material evidence, considered in time and space. Using traces of human activity, such as artefacts and habitats, it determines the spatial distribution and density of populations at different moments in time, giving a dynamic picture of settlement patterns in the areas under study. This research field is mainly that of archaeologists and geographers who apply specific qualitative models, developed in the fields of ecology, resource availability (carrying capacity) and economics, to quantitative data in order to track the evolution of populations, often observed over very long periods (especially in prehistory). Andrew Chamberlain $(2006,2009)$ proposes an interesting overview on the possibilities and the limits of archaeological demography. However, even when it can be established that population size is proportional to the quantity of material evidence uncovered, it is not easy to convert this evidence of resource usage into actual population numbers. This approach is, therefore, better suited to analysis of changes over time in relative rather than absolute population size. The recent work of Palmisano et al. (2017), for example, using a multi-proxy approach, compares several different archaeological indices to assess the extent to which they corroborate or diverge from one another to model the population dynamics in central Italy from Neolithic times to the fall of the Roman Empire.

Palaeodemography, based on the analysis of buried or cremated human remains, aims to reconstruct the age-sex distributions of one or more sets of individuals at the time of death, based on the assumption of human biological uniformity (see Buchet and Séguy 2002; Hoppa and Vaupel 2002a; Bocquet-Appel 2008; Séguy and Buchet 
2013). Attempts to understand fertility behaviours have not been so successful, but the recent study by McFadden and Oxenham (2017) offers some promise. Bones and teeth provide information that can be used by demographers to determine sex and age at death or, more precisely, to indicate the stage of growth or ageing reached by individuals when they died. This biological material also provides information on health status, activities, pathologies, nutrition, breastfeeding patterns, genetic relationships and migratory behaviours of buried populations. The palaeodemographic approach borrows from forensic medicine (even if its goals are fundamentally different) and demography.

Although written sources and material evidence are often studied separately, they also can be used jointly in a holistic approach (Fig. 2.1).

\subsection{A Brief Overview of Roman Demographic Behaviours}

\subsubsection{Roman Population Size and Structures}

Apart from the ongoing scholarly debate about population numbers in Roman Italy (see Hin 2008, 2015, with an intermediate position between Brunt 1987 and Lo Cascio 1994), there appear to be no estimates of local or regional population size, except for Roman Egypt (see, e.g. Lo Cascio 1997, Storey 1997 and Morley 2013 on the size of the population of Rome, in connection with the estimation of the
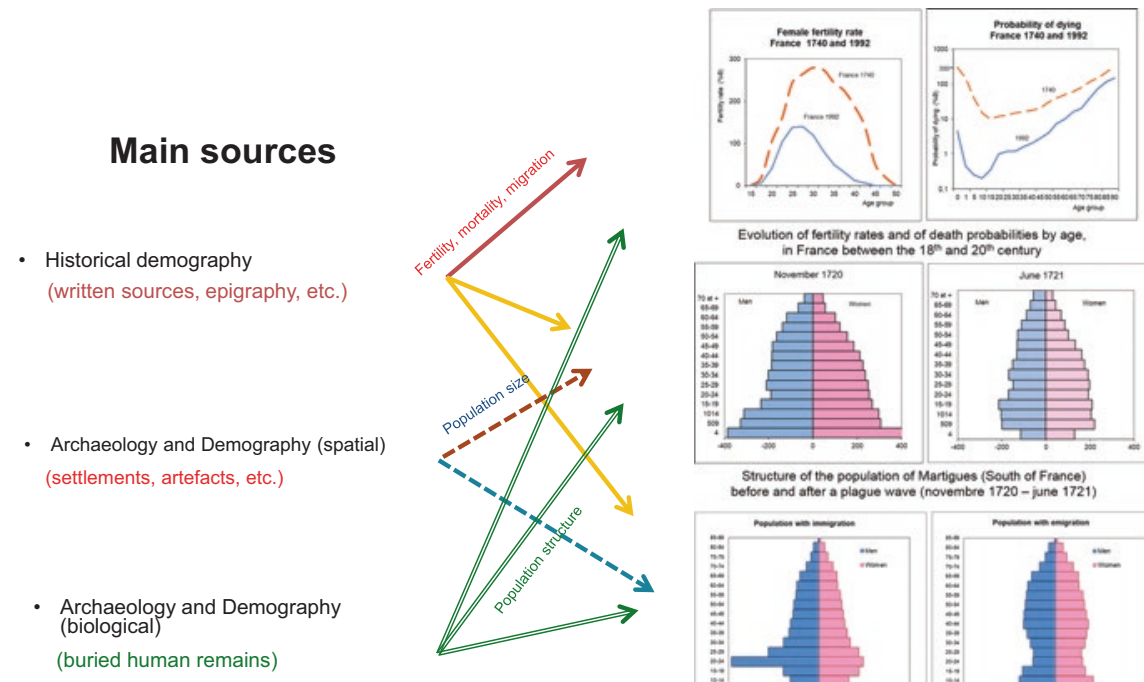

Evolution of fertitity rates and of death probabilities by age,
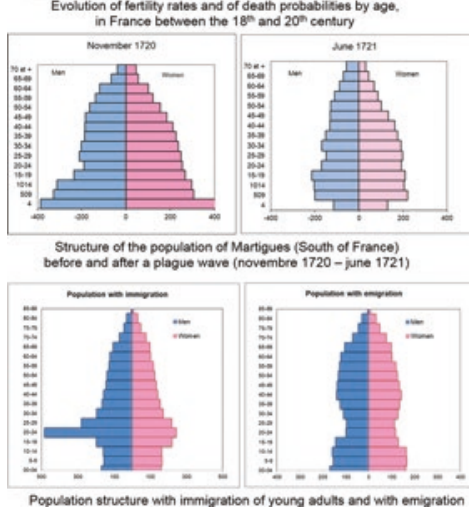

Fig. 2.1 Contributions of the different sources to demographic parameters. (Source: author's previous work) 
population of Roman Italy; see also Launaro 2011 focusing on the rural population of Roman Italy, McIntyre 2015 estimating the size of the population of Roman York from human skeletal remains and the recent methodological proposition of Hanson and Ortman 2017).

Although numerous censuses were conducted throughout the Roman Empire to "identify taxpayers and recruit soldiers" (Le Teuff 2012), no estimates of provincial or urban populations can be given. The Brevarium totius imperii, requested by Emperor Augustus to provide an inventory of the Empire's material and human resources, has totally disappeared (Le Teuff 2014, 87-88). We have already pointed out the difficulties inherent to archaeological approaches. For villages, towns and city-scale settlements, no single constant can be employed to convert settlement area into population size, as there are wide inter-regional variations in the spatial density of human settlement. But a regular relationship between the area of Roman military camps and the size of the forces that occupied them has been proposed by Richardson (2000) who calculated a density of 127 persons/ha for these camps.

Very little is also known about the age-sex structures of Roman populations. Moreover, these structures may have differed widely from one group to another, and from one place to another, particularly in the context of large-scale immigration or emigration (Fig. 2.1c). The Roman population was a preindustrial one, probably with high infant mortality and high fertility; so one might expect to find a triangular population pyramid with a wide base that tapers inwards towards the top. However, exceptional levels of urbanization, as was the case in Rome, were liable to modify the population structure and the demographic parameters of mortality and fertility.

\subsubsection{Fertility}

Fertility is usually considered in relation to marital status, but while we have some information about the nuptiality of Roman elites (e.g. see Grubbs 1995; George 2005; Bodel and Olyan 2008; Hübner and Ratzan 2009; Rawson 2011; Harlow and Larsson Lovén 2012; Hübner and Nathan 2017), we know quite nothing about nuptiality patterns for other social categories or about concubinage practices (see, e.g. Phang 2001 and Scheidel 2005 on the varied conjugal relationships of soldiers in the Roman Empire). So, the simplest option is to calculate the mean number of children per women (total fertility rate) necessary to ensure population replacement, regardless of marital status. According to demographic models, a population with low life expectancy at birth $^{3}$ needs four to six children per woman to maintain replacement levels under these conditions of mortality and many more, of course, to achieve a positive growth rate. Reproductive behaviours are highly variable in time and space and across socio-economic groups; they are also affected by mortality

\footnotetext{
${ }^{3}$ Generally estimated to be between 20 and 30 years, signifying that one in two children died before adulthood.
} 
levels, especially at reproductive ages. That is true both under normal conditions and in times of crisis.

Bruce Frier (1994) calculated a natural fertility pattern (theoretical number of children a woman can bear during her reproductive life) and compared it with the marital fertility of Egyptian women during Roman domination. The difference between the observed and the expected rates reflects the influence of factors limiting natural fertility, both biological factors such as female mortality before or during reproductive life, frequent divorce, widowhood and sterility and cultural behaviours such as prolonged breastfeeding, sexual taboos and birth control within families.

Using osteological data, Jean-Pierre Bocquet-Appel revealed changes in fertility following the transition from a nomadic hunter-gatherer lifestyle to the sedentary lifestyle of the first farmers; or more exactly, the consequences of this change in terms of child mortality (Bocquet-Appel 2002; Bocquet-Appel and Bar Yosef 2008). By observing the proportion of juvenile skeletons in cemeteries from Mesolithic and Neolithic times, i.e. the Juvenility index (the ratio of 5- to19-year-old skeletons to all skeletons 5 or more years old), and by using a relative chronology to fix the starting point $\left(\mathrm{t}_{0}\right)$ of the transition from foragers to farmers in each place, regardless of the precise date when it actually occurred, he demonstrates that throughout the world, the transition from foragers to farmers was characterized by an abrupt increase in the proportion of juvenile skeletons, which expresses a corresponding increase in the parameter values for entry into the population age pyramid (birth, growth and fertility rate). He named this starting point the "Neolithic Demographic Transition" in reference to the Contemporary Demographic Transition, described for industrialized societies, when the decline in mortality was followed by a decline in fertility.

Adopting a different approach, Pennington (1996) showed that the transition from nomadic to sedentary lifestyles could substantially increase young children's chances of survival. A very small mortality gain is sufficient to create the conditions for substantial population growth without any increase in birth rates.

\subsubsection{Mortality}

Few sources can be used to study mortality by sex and age. Funerary inscriptions provide information about age at death, but these statistics are not reliable indicators of mortality rates and life expectancy (Henry 1959). The same arguments apply with respect to documentary evidence about members of the Roman elites. Census records from Roman Egypt give an idea of the life expectancy of ordinary citizens (Bagnall and Frier 2006), but most of the mortality data are empirically based on model life tables for low-life-expectancy populations derived from contemporary model life tables (see Parkin 1992; Scheidel 1996, 2001; Bagnall and Frier 2006; Woods 2007; Hin 2013). Thus, distributions by age at death, age-specific mortality rates and low life expectancies (between 20 and 30 years) are extrapolations. 
Because infant mortality data are missing in historical sources, these researchers all used Coale and Demeny's model life Tables (1983), which are based on observed life tables, mostly from developed countries (overwhelmingly European), some dating from the nineteenth century. None of these populations had a life expectancy at birth of less than 30 years; the parameters for populations with a lower life expectancy at birth are extrapolated. Considering this fact and the huge change in mortality pattern in the last two centuries, Séguy et al. developed a set of mortality models for preindustrial populations, taking into account theoretical growth rates which can be applied in palaeodemographic approaches (Séguy et al. 2008; Séguy and Buchet 2013), as well as in other fields of research. These statistical and pre-statistical life tables characterizing the mortality of preindustrial populations are called the "preindustrial standard".

Moreover, these parameters doubtless varied considerably across the Roman Empire, depending on environmental conditions, socio-economic status and gender. See, for example, Sallares (2002) and Scheidel (2015) on malaria in ancient Rome, Lo Cascio (2012) on the "Antonine Plague" of 165-190 AD which affected some places but spared neighbouring ones and Harper (2014) on epidemics of the third century AD.

Archaeo-osteological data can provide evidence of demographic perturbations that were sufficiently intense to leave long-term traces. Using the method proposed by Henri Caussinus and Daniel Courgeau (2010, 2013), ${ }^{4}$ a recent study on a buried population in Normandy revealed that demographic conditions in Merovingian times were less favourable than in Gallo-Roman times (Buchet et al. 2017). Significant differences in the age distribution of death from one period to another were noted: the age distribution was very close to the preindustrial standard during the Gallo-Roman period, while mortality was higher, particularly at young ages, during Merovingian times. These differences may be due to a variation in the age mortality distribution or to differences in the population structure (by sex and age) to which the same age-at-death distribution is applied (or both). Both hypotheses are plausible in light of the available archaeological evidence. A forthcoming paper confirms this point for a sample of cemeteries in northern France (Séguy et al. 2017, forthcoming).

\subsubsection{Migration}

Migration, the third component of population dynamics, is rather difficult to evaluate and tends to be the "poor cousin" of historical demographic analysis (it is much easier to analyse populations with no migration), especially since historians long believed that rural populations were immobile.

\footnotetext{
${ }^{4}$ This method, called Bayesian Inference Procedure, is based on the principle of Bayesian inference and uses a parametric formulation of the problem, as recommended by the Rostock Manifesto (Hoppa and Vaupel 2002b).
} 
Migration refers to the process whereby individuals enter or leave a population other than through birth or death. It is a special instance of spatial mobility, distinct from the regular movements within a territory that are undertaken by nomadic peoples, itinerant workers and traders (in these cases, the more appropriate term is "circulation"; see Pressat 1985). People migrate for different reasons (Coleman 2004, 36):

- Mobility (e.g. short distance movements for trade, work or marriage)

- Conquest (migration of a small number of people who impose their laws and their organization upon another population, despite their numerical inferiority)

- Mass migration (Völkerwanderung) (movements of entire peoples, with their hierarchies and their livelihoods, in search of new lands or expelled by other peoples)

- Forced migration

- Infiltration ("infiltration" of foreigners unopposed by the local population, with no change of governing class nor allegiance to an outside power; ex-missionaries, refugees)

- Deportation (different from the forced migration in the sense that it consists in capturing individuals or whole communities, extracting them from their territories of origin and selling them as slaves either for hard labour or for army enlistment, e.g. slave trade)

- Invitation to immigrate (when a state or a city invites individuals or groups to immigrate in order to increase its own population and revive its economy, for example, after the heavy losses of the Black Death).

Of course, to analyse migration, the population concerned must have recognizable boundaries, usually defined for human populations in terms of the individuals' places of permanent residence. Migration also implies the existence of two populations (donor and recipient); but as migrants' mortality and fertility characteristics may differ from those of both donor and recipient populations, they constitute a third population group.

In demography, studying migration is complex because, unlike birth and death which are singular and irreversible events, an individual can participate in more than one migration event. Human migration is also difficult to model and predict because it depends on individual decision-making, ${ }^{5}$ and on fluctuating demographic, economic and political circumstances, both in donor and recipient populations. From a socio-economic point of view, migration can influence a society's culture and economy (crafts, agriculture, fishing, trade and so on), its environment and carrying capacity. It may also accelerate the spread of infectious diseases, or generate insecurity and the destruction of harvests (leading to famine and malnutrition) in case of war or conquest. Last but not the least, it also modifies population genetics.

These questions are now widely studied by historians, archaeologists and bioanthropologists whose findings, sometimes presented in multidisciplinary collective

\footnotetext{
${ }^{5}$ Migration incentives include work opportunities, improved living conditions, and the desire to escape from objective hazards such as conflict and epidemics.
} 
works (see, e.g. Eckardt 2010; De Ligt and Tacoma 2016; Yoo and Zerbini 2018), show the importance of mobility and migration in the Roman world and examine how differences were expressed in both the host and migrant communities and how identities were maintained and evolved over time (see Noy 2000; Roymans 2004; Derks and Roymans 2009). Material artefacts allow the identification of migrants, at least for the first generations, while human remains provide individual information, mainly derived from isotopic (see, e.g. Killgrove and Montgomery 2016; Gowland 2017) and DNA (MtDNA or nuclear DNA) analyses.

\subsection{Demographic Dynamics of Limes Populations over the Long Term: An Empirical Approach}

\subsubsection{One Border Zone, But Very Diverse Populations}

The Limes Germanicus, a border zone between the Roman Empire and the peoples of Northern Europe, has some highly specific features: (1) a very large military presence, (2) major population movements (migrations) that took different forms over time, (3) a colonization process resulting from the settlement of demobilized soldiers and (4) small-scale urbanization or, more precisely, population concentration in camps or small towns, in sparsely populated territories.

Analysis of demographic behaviours, over both the short and long term, must therefore be conducted with considerable flexibility. Studies of immigrant populations reveal differences in behaviour between the recipient and donor countries and between immigrants and natives; they also show a relatively rapid convergence between the demographic behaviours of immigrants' and natives' children or grandchildren. Other studies on the demography of frontier populations ${ }^{6}$ highlight the interpenetration of their cultural behaviours (Renard 1992). These studies are certainly helpful for shedding light on the demographic dynamics of the limes. However, it is not sufficient to simply describe the particularities of this population, or of the historical period in question.

The limes $^{7}$ was not a clearly demarcated area, despite its fortifications, but probably an area of mixing and intercommunication, where population groups of very

\footnotetext{
${ }^{6}$ Contemporary frontiers separate two distinct spaces characterized by different population, health policies and different levels of economic development.

${ }^{7}$ Lively debate among historians on the notion of "frontier" - a clear boundary between two territories or a "no man's land" with no clear demarcation? - has led to a new perception of the limits of the Roman Empire. The limes was not so much a frontier, as defined today, but a "patrol route" as suggested by the etymology of the word. Often following natural barriers, the role of the line of fortifications was less to separate the Romans from the Barbarians than, in military terms, to establish major bridgeheads and an effective surveillance system and, in political economic terms, to create mandatory points of passage to control population movements and levy taxes on traded goods. The importance of the different functions varied according to the level of tension or harmony in relations with neighbouring (Germanic) populations.
} 
different origins and statuses intermingled (Morin 2011a). Not only did the garrisons include foreign soldiers from throughout the Empire (see Roselaar 2016), but the busy trade generated by their presence attracted merchants and artisans from both southern and northern Europe. All these "foreigners" lived side by side with local populations, sometimes in close contact, given that the legion auxiliaries were recruited from among native people or married local women and that the legionnaires settled beyond the boundaries of the limes.

In demographic terms, this mixing gave rise to dynamics and behaviours that must have varied considerably between the Roman or Romanized populations, the inhabitants originating from Germania Magna and the mosaic of people's native to the limes, a region of "convergence", to use the expression coined by Mélissa Morin (2011b), and of acculturation (Bloemers 1983, 1989; Blagg and Millett 2016).

\subsubsection{A Migrant Population with a Skewed Sex Ratio}

The demography of the limes was thus characterized by intense and varied forms of migration (cf. supra) which also varied over time. For the first generations, the demographic dynamics were probably shaped less by natural population change than by migration. In the early days of the limes, despite the massive influx of soldiers and forced population displacement, the conditions probably did not favour natural population growth. On the contrary, the departure of inhabitants who fled the region or were sent away as slaves and the increased mortality and lower fertility associated with insecure living conditions must have reduced the size of populations and modified their age-sex structure (cf. Fig. 2.1). By comparison with other historical situations, it is reasonable to imagine that the massive influx of men, but also of women and young adolescents in the context of military conquest, produced a psychological shock (and perhaps an epidemiological shock, cf. infra) with physiological repercussions. Though covering a different region, a statistical comparison of pre- and post-colonial skeletal remains by Kyle et al. (2016) revealed the physical stigmata of the stresses inflicted upon the population of Apollonia (in present-day Albania) after the Greek colonization in the sixth century BC. The authors attribute this physiological stress to a reduction in locally available resources and the adverse health impact of urbanization (insalubrity and propagation of disease).

Apart from the negative effects on population growth of war, forced migration and constant insecurity, the unprecedented concentration of people living in camps and towns also created conditions for radical demographic regime changes, potentially masked by the spectacular increase in numbers of inhabitants. In the same way as the sedentarization of Neolithic populations profoundly modified their fertility and the mortality of their young children, the rapid "urbanization" of previously scattered populations may have produced new fertility behaviours and mortality patterns. In addition, the assignment by Rome of officials to one town rather than another may also have modified the appeal of certain territories over time. This is suggested in a study by Ouriachi and Nuninger (2011) who cross-linked a spatial 
model of the settlement system in a region of southern France and an analysis of the local gentry's social networks, revealing the existence of competition, not only between individuals for administrative positions but also between towns wishing to attract the most influential officials and thereby raise their prestige. The spatial distribution of the population and its density thus depend not only on the numbers of migrants, but also on the quality of the most high-ranking ones.

In more peaceful times, the age-sex structure of the population around the limes was highly favourable for positive demographic dynamics and population growth. The predominant presence of young, affluent men clearly oriented the marriage market in favour of soldiers and legion auxiliaries. Phang (2001) draws upon funerary epitaphs to show the types of relationships that existed among soldiers. Soldiers who married did so later, in their mid-thirties, and their wives were usually from the families of military comrades. Soldiers could find a partner, live with her and have offspring in a union not legally recognized under Roman law. Penelope Allison (2008) investigated the presence, activities and status of women and children in Roman military forts on the German frontier during the first and second centuries AD. She concluded that women played a greater role in military life in the early Roman Empire than has previously been acknowledged (see also Allison 2011, 2013). Elisabeth Greene (2011) provides evidence for the presence of women and children within military garrisons during the earliest periods of military conquest and during consolidation in the first and second centuries AD. In the first century $\mathrm{AD}$, the auxiliary units stationed on the frontiers of the western provinces were legally allowed to cohabit with women during their period of service; soldiers were later granted the same right. A comparison can be made with the soldiers present in the same zone some centuries later (see the doctoral work by Dana Rus 2010, 2016 on Roman border guards in the late eighteenth and nineteenth centuries).

Such marriages created new ties on other side of the "border", or rather consolidated existing ones, since other practices had the same purpose (recruitment of local auxiliaries, allocation of land behind the limes to legionnaires, reception of hostages, etc.), thus forming a sort of giant human shield (e.g. Picard 2014 and Boatwright 2015 on forced displacements; Foubert 2011 on migration of highranking women; Moatti 2017a and b on legal evidence and categorization of migrants; and Lo Cascio and Tacoma 2017 on the impact of mobility and migration). The establishment of human populations in the limes doubtless owes much to these marriage migrations and to higher fertility (and better child survival) made possible by material wealth and better health conditions.

\subsubsection{Demographic Crises Were Inevitable}

Generally stemming from insecurity and social and economic difficulties, recurrent demographic crises are a characteristic of preindustrial population dynamics. These brief, but intense, episodes of excess mortality (often accompanied by fewer marriages and births) most likely affected the populations of the limes, 
and the general curve of population growth doubtless includes a number of sudden dips.

While mortality is correlated with advancing age as much as with the perils of early childhood, it is also highly sensitive to random events that may modify its intensity and selectivity. When the limes was established, a road network was built that facilitated troop movements, food transport and trade, but also the circulation of infectious diseases. And the large migrant inflows inevitably brought in new diseases that produced epidemics which were especially severe if the populations had no prior exposure and, therefore, no immunity to the pathogen. One such example was the epidemic of smallpox, known as "Antonine Plague", that swept across the Roman Empire between 165 and 190 AD, spread by soldiers returning from campaigns in the Near East (Lo Cascio 2012). It was described in detail by Galen of Pergamon, a contemporary physician, enabling historians (Littman and Littman 1973) to recognize it as haemorrhagic smallpox, a virulent and highly lethal form of the disease. They agree that the epidemic hit a previously unaffected population, resulting in higher mortality than in subsequent outbreaks.

Living close to major communication routes or in crowded towns or military camps greatly increased the risk of contagion, with consequences in terms of excess mortality. In demographic, economic and geopolitical terms, the actual impact of Antonine Plague across the Empire remains uncertain (estimated mortality rates range from 7-10\%, following Littman and Littman 1973, to 25-33\%, according to Duncan-Jones 1996 and Zelener 2003). More certain is the series of epidemics that struck the Roman world between the second and the sixth centuries $\mathrm{AD}$, causing a significant population decrease and contributing, along with many other factors, to the decline of the Roman Empire (see Little 2007; Harper 2014).

Indeed, after a long period of climatic stability and limited volcanic activity between $100 \mathrm{BCE}$ and $150 \mathrm{AD}$ (McCormick et al. 2012), climate conditions worsened. Some scientists have postulated that major volcanic eruptions produced severe weather disturbances, which destroyed crops and led to famine and disease. The scale of these climatic repercussions is still a topic of debate. However, as northern Europe was particularly exposed to the after-effects of Icelandic volcanic eruptions, it is reasonable to imagine that it endured several years of poor harvests. Between 150 and $200 \mathrm{AD}$, when climatic conditions began to deteriorate, the Empire was confronting a major economic and political crisis and a number of military challenges (McCormick et al. 2012, 203).

Given the close correlation between climate and food resources (cf., e.g. Bevan et al. 2017), such change is generally accompanied by episodes of food shortage or famine, which adversely affect the populations and increase their susceptibility to disease and epidemics. The populations of the limes must have been severely exposed to such risks, first because of the high population density (and the absolute priority given to supplying the garrisons) and, second, because the region was unable, even under normal conditions, to meet the population's food needs and relied on imports, themselves in short supply when the producer regions no longer had a surplus (see, e.g. the calculation models proposed by Van Dinter et al. 2014 and Chap. 7, Joyce, to estimate the local carrying capacity). 

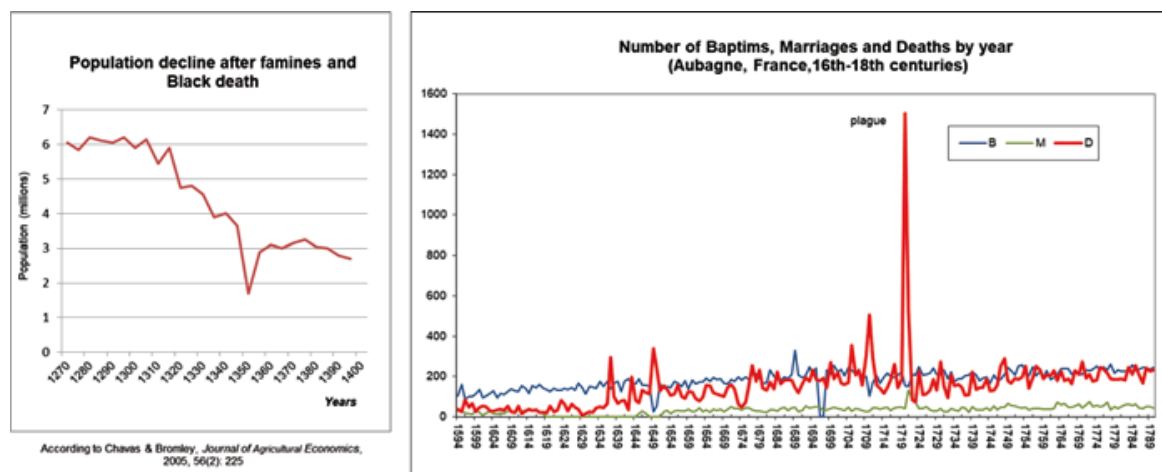

Fig. 2.2 Short- and long-term impact of demographic crises (detection of excess mortality crises in the vital records of Aubagne, English population decline up to the arrival of the Black Death). (Sources: author's previous studies and Chavas and Bromley (2005))

Chronic and acute malnutrition (famine) and the accompanying disease and epidemics caused by wars or poor climatic conditions give rise to excess mortality, but also result in a deficit of births that is proportional to the severity of the famine and its duration. Famines also encourage migration and can lead to local population decline. Recurrent severe demographic crises can hinder demographic recovery.

\subsubsection{A Faltering Demographic Recovery}

Demographic crises that decimate young adults (such as the plague or influenza) often have a more pronounced long-term impact; the population size and structure are such that the population cannot immediately renew itself despite the generally observed increase in birth rates (Fig. 2.2). Most often, it is regenerated through the arrival of new immigrants but only if neighbouring regions have not themselves been severely affected. Populations are more resilient over the short term when difficulties are short-lived or only affect young children. Yet repeated food shortages and cyclical epidemics of childhood diseases may hinder demographic growth, with population size remaining practically constant over the long term. Preindustrial populations were confronted by these regulatory mechanisms, which are linked to epidemic thresholds ${ }^{8}$ and to environmental carrying capacity. ${ }^{9}$

The worsening environmental conditions in the second half of the third century, and mainly the cooling that affected the north-western provinces of the Empire (McCormick et al. 2012), could have severely disrupted food production and slowed

\footnotetext{
${ }^{8}$ i.e. the number or density of receptive individuals required for an epidemic to take hold.

${ }^{9}$ i.e. at the prevailing levels of technological development, the maximum population size that can be sustained indefinitely, in terms of food, water, living space, energy, etc., by a given environment.
} 
down the recovery capacities of populations. Economic difficulties often encourage those who have nothing (or nothing left) to migrate. If emigration occurs on a large scale, such movements can hinder demographic recovery and lead to a significant decline in local settlement.

\subsection{Conclusions}

In demographic terms, the limes was a specific and complex territory where different populations intermingled and where trade was conducted on a large scale. A remarkable instrument of acculturation but also an ideal environment for the propagation of new contagious diseases, the limes doubtless exhibited very specific demographic structures and behaviours which evolved in response to the levels of security or insecurity experienced by its populations. It is difficult to model demographic behaviours in a region such as this, as Verhagen et al. (2016) can confirm. The "migration" parameter is of key importance, yet difficult to quantify or predict. Apart from migration linked to militarization and forced population displacements, migration behaviours, like those of fertility and mortality, are governed as much by individual and family decisions as by parameters of well-being and security.

This rapid overview of historically attested demographic situations does not take account of data provided by the documents and archaeology of the limes. Its sole purpose is to suggest some avenues for future research to better understand the factors underlying the long-term population dynamics of the region.

Acknowledgements The author thanks Catriona Dutreuilh (INED) for the English version of her text.

\section{References}

Allison PM (2008) Measuring Women's Influence on Roman Military Life: using GIS on published excavation reports from the German frontier. Internet Archaeology 24. https://doi. org/10.11141/ia.24.5

Allison PM (2011) Soldiers' families in the early Roman Empire. In: Rawson B (ed) A companion to families in the Greek and Roman worlds. Blackwell Publishing, Oxford, pp 161-182. https:// doi.org/10.1002/9781444390766.ch10

Allison PM (2013) People and spaces in Roman military bases. Cambridge University Press, Cambridge. https://doi.org/10.1017/CBO9781139600248

Bagnall RS, Frier BW (2006) The demography of Roman Egypt, 2nd edn. Cambridge University Press, Cambridge

Bevan A, Colledge S, Fuller D, Fyfe R, Shennan S, Stevens C (2017) Holocene population, food production, and climate. PNAS 14(49):E10524-E10531. https://doi.org/10.1073/ pnas. 1709190114

Blagg TFC, Millett M (2016) The early Roman empire in the west. Oxbow, Oxford 
Bloemers JHF (1983) Acculturation in the Rhine/Meuse Basin in the Roman Period: a preliminary survey. In: Brandt RW, Slofstra J (eds) Roman and Native in the Low Countries, Spheres of interaction. BAR, Oxford, pp 159-209

Bloemers JHF (1989) Acculturation in the Rhine/Meuse Basin in the Roman Period: some demographical considerations. In: Barrett JC, Fitzpatrick AP, MacInnes L (eds) Barbarians and Romans in North-West Europe from the later Republic to late Antiquity. BAR, Oxford, pp 175-234

Boatwright MT (2015) Acceptance and approval: Romans' Non-Roman population transfers, 180 BCE-ca 70 CE. Phoenix 69(1/2):122-146. https://doi.org/10.7834/phoenix.69.1-2.0122

Bocquet-Appel J-P (2002) Paleoanthropological traces of Neolithic demographic transition. Curr Anthropol 43:638-650. https://doi.org/10.1086/342429

Bocquet-Appel J-P (ed) (2008) Recent advances in paleodemography: data, techniques, patterns. Springer, Dordrecht. https://doi.org/10.1007/978-1-4020-6424-1

Bocquet-Appel J-P, Bar Yosef O (eds) (2008) The Neolithic demographic transition and its consequences. Springer, Dordrecht. https://doi.org/10.1007/978-1-4020-8539-0

Bodel JM, Olyan S (eds) (2008) Household and family religion in antiquity. Blackwell, Oxford. https://doi.org/10.1002/9781444302974

Brunt PA (1987) Italian manpower 225 B.C. - A.D. 14, 2nd edn. Oxford University Press, Oxford

Buchet L, Séguy I (2002) La paléodémographie aujourd'hui: bilan et perspectives. Annales de démographie historique 1:161-212. https://doi.org/10.3917/adh.103.0161

Buchet L, Caussinus H, Courgeau D, Séguy I (2017) Atouts d'une procédure récente d'inférence bayésienne pour l'étude de l'impact des crises démographiques. Application à trois sites médiévaux bas-normands. Bull Mém Soc Anthropol Paris 29(1):70-84. https://doi.org/10.1007/ s13219-016-0175-4

Caussinus H, Courgeau D (2010) Estimating age without measuring it: a new method in paleodemography. Population-E 65(1):117-144. https://doi.org/10.3917/pope.1001.0117

Caussinus H, Courgeau D (2013) A new method for estimating age-at-death structure. In: Séguy I, Buchet L (eds) Handbook of palaeodemography. Springer, Dordrecht, pp 255-286. https://doi. org/10.1007/978-3-319-01553-8_13

Chamberlain AT (2006) Demography in archaeology. Cambridge University Press, Cambridge. https://doi.org/10.1017/CBO9780511607165

Chamberlain AT (2009) Archaeological demography. Hum Biol 81(2-3):275-286. https://doi. org/10.3378/027.081.0309

Chavas J-P, Bromley D (2005) Modelling population and resource scarcity in fourteenth-century England. J Agric Econ 56(2):217-237. https://doi.org/10.1111/j.1477-9552.2005.00001

Coale AJ, Demeny P (1983) Regional model life tables and stable populations, 2nd edn. Academic Press, New York

Coleman DA (2004) Le rôle majeur de la migration dans les processus démographiques. In: Caselli G, Vallin J, Wunsch G (eds) Traité de démographie. Démographie. Analyse et synthèse, tome V: Histoire du peuplement et des prévisions. INED, Paris, pp 33-69

De Ligt L, Northwood S (eds) (2008) People, land, and politics: demographic developments and the transformation of Roman Italy, 300 BC-AD 14. Brill, Leiden. https://doi.org/10.1163/ ej.9789004171183.i-656

De Ligt L (2012) Peasants, citizens and soldiers: studies in the demographic history of Roman Italy 225 BC-AD 10. Cambridge University Press, Cambridge. https://doi.org/10.1017/ CBO9781139003834

De Ligt L, Tacoma LE (2016) Migration and mobility in the early Roman Empire. Brill, Leiden

Derks T, Roymans N (eds) (2009) Ethnic constructs in antiquity: the role of power and tradition. Amsterdam University Press, Amsterdam. https://doi.org/10.5117/9789089640789

Duncan-Jones RP (1996) The impact of the Antonine plague. J Roman Archaeol 9:108-136. https://doi.org/10.1017/S1047759400016524

Eckardt H (ed) (2010) Roman Diasporas: archaeological approaches to mobility and diversity in the Roman Empire. Journal of Roman Archaeology, Portsmouth 
Foubert L (2011) The impact of women's travels on military imagery in the Julio-Claudian period. In: Hekster O, Kaizer T (eds) Frontiers in the Roman World. Proceedings of the Ninth Workshop of the International Network Impact of Empire (Durham, 16-19 April 2009). Brill, Leiden, pp 349-362. https://doi.org/10.1163/ej.9789004201194.i-378.78

Frier BW (1994) Natural fertility and family limitation in Roman marriage. Class Philol 89(4):318 333. https://doi.org/10.1086/367430

George M (2005) The Roman family in the empire: Rome, Italy, and beyond. Oxford University Press, Oxford. https://doi.org/10.1093/acprof:oso/9780199268412.001.0001

Gowland RL (2017) Embodied identities in Roman Britain: a bioarchaeological approach. Britannia 48:175-119. https://doi.org/10.1017/S0068113X17000125

Grubbs JE (1995) Family and law in late antiquity: the emperor Constantine's marriage legislation. Oxford University Press, Oxford

Greene EM (2011) Women and families in the auxiliary military communities of the Roman west in the first and second centuries AD. University of North Carolina, Chapel Hill

Hanson JW, Ortman SG (2017) A systematic method for estimating the populations of Greek and Roman settlements. J Roman Archaeol 30:301-324. https://doi.org/10.1017/ S1047759400074134

Harlow M, Larsson Lovén L (eds) (2012) Families in the Roman and late antique world. Continuum, London/New York

Harper K (2014) Pandemics and passages to late antiquity: rethinking the plague of c.249-270. J Roman Archaeol 28:223-260. https://doi.org/10.1017/S1047759415002470

Henry L (1959) L'âge au décès d'après les inscriptions funéraires. Population 14(2):327-329. https://doi.org/10.2307/1526414

Hin S (2008) Counting Romans. In: De Ligt L, Northwood S (eds) People, land, and politics: demographic developments and the transformation of Roman Italy, 300 BC-AD 14. Brill, Leiden, pp 187-238

Hin S (2013) The demography of Roman Italy: population dynamics in an ancient conquest society, 201 BCE-14 CE. Cambridge University Press, Cambridge. https://doi.org/10.1017/ CBO9780511782305

Hin S (2015) Ancient demography. In: Clayman DL (ed) Oxford bibliographies in classics. Oxford University Press, Oxford. https://doi.org/10.1093/obo/9780195389661-0208

Holleran C, Pudsey A (2011) Introduction: studies in ancient historical demography. In: Holleran C, Pudsey A (eds) Demography and the Graeco-Roman world: new insights and approaches. Cambridge University Press, Cambridge, pp 1-13. https://doi.org/10.1017/ CBO9780511863295.001

Hoppa RD, Vaupel JW (2002a) Paleodemography: age distributions from skeletal samples. Cambridge University Press, Cambridge. https://doi.org/10.1017/CBO9780511542428

Hoppa RD, Vaupel JW (2002b) The Rostock Manifesto for paleodemography: the way from stage to age. In: Hoppa RD, Vaupel JW (eds) Paleodemography: age distributions from skeletal samples. Cambridge University Press, Cambridge. https://doi.org/10.1017/CBO9780511542428.001

Hübner SR, Ratzan DM (eds) (2009) Growing up fatherless in antiquity. Cambridge University Press, Cambridge. https://doi.org/10.1017/CBO9780511575594

Hübner SR, Nathan G (eds) (2017) Mediterranean families in antiquity: house-holds, extended families, and domestic space. John Wiley \& Sons, Oxford

Killgrove K, Montgomery J (2016) All roads lead to Rome: exploring human migration to the Eternal City through biochemistry of skeletons from two imperial-era cemeteries (1st-3rd c AD). PLoS ONE 11(2):e0147585. https://doi.org/10.1371/journal.pone.0147585

Kyle B, Schepartz LA, Larsen CS (2016) Mother city and colony: bioarchaeological evidence of stress and impacts of Corinthian Colonisation at Apollonia. Int J Osteoarchaeol 26:1067-1077. https://doi.org/10.1002/oa.2519

Launaro A (2011) Peasants and slaves: the rural population of Roman Italy (200 BC to AD 100). Cambridge University Press, Cambridge 
Le Teuff B (2012) Census: les recensements dans l'empire romain d'Auguste à Diocletien. Université Michel de Montaigne - Bordeaux III, Bordeaux

Le Teuff B (2014) Les recensements augustéens aux origines de l'Empire. Pallas (96):75-90. https://doi.org/10.4000/pallas.1179

Little LK (ed) (2007) Plague and the end of antiquity: the pandemic of 541-750. Cambridge University Press, Cambridge

Littman RJ, Littman ML (1973) Galen and the Antonine Plague. Am J Philol 94(3):243-255. https://doi.org/10.2307/293979

Lo Cascio E (1994) La dinamica della popolazione in Italia da Augusto al III secolo. Publications de l'École française de. Rome 198(1):91-125

Lo Cascio E (1997) Le procedure di recensus dalla tarda repubblica al tardo antico e il calcolo della popolazione di Roma. In: La Rome impériale: démographie et logistique. Actes de la table ronde de Rome, 25 mars 1994. Publications de l'École française de Rome 230, pp 3-76

Lo Cascio E (ed) (2012) L'impatto della "Peste Antonina". Edipuglia, Bari

Lo Cascio E, Tacoma LE (eds) (2017) The impact of mobility and migration in the Roman Empire. Brill, Leiden

McCormick M, Büntgen U, Cane MA, Cook ER, Harper K, Huybers P, Litt T, Manning SW, Mayewski PA, More AFM, Nicolussi K, Tegel W (2012) Climate change during and after the Roman Empire: reconstructing the past from scientific and historical evidence. J Interdiscip Hist 43(2):169-220. https://doi.org/10.1162/JINH_a_00379

McFadden C, Oxenham MF (2017) The D0-14/D ratio: a new paleodemographic index and equation for estimating total fertility rates. Am J Phys Anthropol 165(3):471-479. https://doi. org/10.1002/ajpa.23365

McIntyre LJ (2015) Reconstructing population size in a Romano-British Colonia: the case of Eboracum. J Roman Archaeol 28:413-429. https://doi.org/10.1017/S1047759415002561

Moatti C (2017a) Les paradoxes de l'immigration dans l'Empire romain. In: Garcia D, Le Bras H (eds) Archéologie des migrations. La Découverte (Recherches/INRAP), Paris, pp 197-210

Moatti C (2017b) Migration et droit dans l'Empire romain: Catégories, contrôles et integration. In: Lo Cascio E, Tacoma LE (eds) The impact of mobility and migration in the Roman Empire. Brill, Leiden, pp 222-245

Morin MS (2011a) Pour une étude des contacts culturels en zone frontalière à l'époque romaine: quelques réflexions conceptuelles. Dialogues d'histoire ancienne 37(2):63-88

Morin MS (2011b) Convergence à la frontière rhénane: les modes de contacts entre les populations frontalières (Ier s. de n. è.). Gerión 29(1):149-168

Morley N (2013) Population size and social structure. In: Erdkamp P (ed) The Cambridge companion to ancient Rome. Cambridge University Press, Cambridge, pp 29-44

Noy D (2000) Foreigners at Rome: citizens and strangers. Duckworth, London

Ouriachi M-J, Nuninger L (2011) Trajectoires des hommes et des établissements: contribution à la modélisation du système de peuplement antique en Languedoc oriental. Revue archéologique de Narbonnaise 44:99-116. https://doi.org/10.3406/ran.2011.1822

Palmisano A, Bevan A, Shennan S (2017) Comparing archaeological proxies for long-term population patterns: an example from Central Italy. J Archaeol Sci 87:59-72. https://doi. org/10.1016/j.jas.2017.10.001

Parkin TG (1992) Demography and Roman Society. Johns Hopkins University Press, Baltimore

Pelgrom J (2012) Colonial Landscapes. Demography, Settlement Organization and Impact of Colonies founded by Rome (4th- 2nd centuries BC). University of Leiden, Leiden

Pennington RL (1996) Causes of early human growth. Am J Phys Anthropol 99:259-274. https:// doi.org/10.1002/(SICI) 1096-8644(199602)99:2<259::AID-AJPA4>3.0.CO;2-U

Phang SE (2001) The marriage of Roman soldiers (13 B.C.-A.D. 235): law and family in the Imperial Army. Brill, Leiden

Picard J-B (2014) Les déplacements contraints de part et d'autre du Danube romain d'Auguste à Trajan. Hypothèses 17(1):197-206. https://doi.org/10.3917/hyp.131.0197

Pressat R (1985) Manuel d'analyse de la mortalité. INED, Paris 
Rawson B (ed) (2011) A companion to families in the Greek and Roman worlds. Wiley-Blackwell, Malden/Oxford

Renard J-P (1992) Populations et frontières: problématiques et méthodes. Espace, populations, sociétés 2:167-184. https://doi.org/10.3406/espos.1992.1523

Richardson A (2000) The numerical basis of Roman camps. Oxf J Archaeol 19(4):425-437. https://doi.org/10.1111/1468-0092.00119

Roselaar ST (2016) State-organised mobility in the Roman Empire: legionaries and auxiliaries. In: De Ligt L, Tacoma LE (eds) Migration and mobility in the early Roman Empire. Brill, Leiden, pp 138-157. https://doi.org/10.1163/9789004307377_008

Roymans N (2004) Ethnic identity and Imperial power. The Batavians in the early Roman Empire. Amsterdam University Press, Amsterdam. https://doi.org/10.5117/9789053567050

Rus D (2010) Mariages et remariages sur le territoire du Deuxième Régiment roumain de frontière à l'époque moderne: perspectives démographiques et anthropologiques. Université de Nantes, Nantes

Rus D (2016) La militarisation de la frontière et les mutations des mentalités en Transylvanie roumaine (1750-1850). In: Catala M (ed) Frontières oubliées, frontières retrouvées: Marches et limites anciennes en France et en Europe. Presses universitaires de Rennes, Rennes p

Sallares R (2002) Malaria and Rome: a history of malaria in antiquity. Oxford University Press, Oxford. https://doi.org/10.1093/acprof:oso/9780199248506.001.0001

Scheidel W (1996) Measuring sex, age and death in the Roman Empire: explorations in ancient demography. Journal of Roman Archaeology, Portsmouth

Scheidel W (2001) Death on the Nile: disease and the demography of Roman Egypt. Brill, Leiden. https://doi.org/10.1163/9789004350946

Scheidel W (2005) Marriage, families, and survival in the Roman imperial army: demographic aspects. Stanford University, Stanford. Available at https://www.princeton.edu/ pswpc/pdfs/ scheidel/110509.pdf. Accessed on 21 June 2018

Scheidel W (2015) Death and the City: ancient Rome and beyond. Soc Hist eJ, mai 2015. https:// doi.org/10.2139/ssrn.2609651

Séguy I, Buchet L, Bringé A (2008) Model life tables for preindustrial populations. First applications in paleodemography. In: Bocquet-Appel J-P (ed) Recent advances in paleodemography: data, techniques, patterns. Springer, Dordrecht, pp 109-141. https://doi. org/10.1007/978-1-4020-6424-1_4

Séguy I, Buchet L (2013) Handbook of paleodemography. Springer, Dordrecht. https://doi. org/10.1007/978-3-319-01553-8

Séguy I, Caussinus H, Buchet L, Courgeau D, Le Forestier C, Paresys C, Richard I (2017) Indirect detection of major demographic events with no written sources (France -6 th-7th centuries). Poster presented at the XXVIIIth IUSSP International Population Conference (Capetown, South Africa, 29 October - 4 November 2017). doi:https://doi.org/10.13140/RG.2.2.36331.23843

Séguy I, Caussinus H, Buchet L, Courgeau D, Le Forestier C, Paresys C, Richard I (forthcoming) Détection indirecte d'événements démographiques majeurs en l'absence de sources écrites (France VIe -VIIle siècles). In: Manuel de statistiques à l'usage des archéologues

Storey GR (1997) The population of ancient Rome. Antiquity 71(274):966-978. https://doi. org/10.1017/S0003598X00085859

Van Dinter M, Kooistra LI, Dütting MK, Van Rijn P, Cavallo C (2014) Could the local population of the Lower Rhine delta supply the Roman army? Part 2: Modelling the carrying capacity using archaeological, palaeo-ecological and geomorphological data. J Archaeol Low Ctries 5(1):5-50

Verhagen P, Joyce J, Groenhuijzen MR (2016) Modelling the dynamics of demography in the Dutch limes zone. In: Multi-, inter- and transdisciplinary research in landscape archaeology. Proceedings of LAC 2014 Conference, Rome, 19-20 September 2014. Vrije Universiteit Amsterdam, Amsterdam. https://doi.org/10.5463/lac.2014.62

Woods R (2007) Ancient and early modern mortality: experience and understanding. Econ Hist Rev 60(2):373-399. https://doi.org/10.1111/j.1468-0289.2006.00367.x 
2 Current Trends in Roman Demography and Empirical Approaches to the Dynamics...

Yoo J, Zerbini A (eds) (2018) Migration and migrant identities in the Middle East from antiquity to the Middle Ages. Routledge, Milton

Zelener Y (2003) Smallpox and the disintegration of the Roman economy after 165 A.D. Ph.D. thesis Columbia University

Open Access This chapter is licensed under the terms of the Creative Commons Attribution 4.0 International License (http://creativecommons.org/licenses/by/4.0/), which permits use, sharing, adaptation, distribution and reproduction in any medium or format, as long as you give appropriate credit to the original author(s) and the source, provide a link to the Creative Commons licence and indicate if changes were made.

The images or other third party material in this chapter are included in the chapter's Creative Commons licence, unless indicated otherwise in a credit line to the material. If material is not included in the chapter's Creative Commons licence and your intended use is not permitted by statutory regulation or exceeds the permitted use, you will need to obtain permission directly from the copyright holder.

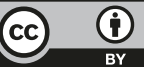

